\title{
Teaching and Learning English Verb Tenses in a Taiwanese University
}

\author{
Pei-ling Wang \\ Applied Foreign Languages Departments, National Kaohsiung University of Applied Sciences \\ 415, Chien-Kung Rd., Kaohsiung, 807, Taiwan \\ Tel: 886-7-381-4526-3276 E-mail: peiling@cc.kuas.edu.tw
}

Received: March 19, 2012

Accepted: April 5, $2012 \quad$ Online Published: June 5, 2012

doi:10.5430/elr.v1n1p18

URL: http://dx.doi.org/10.5430/elr.v1n1p18

\begin{abstract}
This study compares the effect of inductive and deductive approaches in teaching English verb tenses to Taiwanese English-majored freshmen of field independent/dependent (FI/FD) cognitive styles. Research questions include: 1) what is the effect of the two approaches on students' learning outcomes? 2) What are the learning outcomes of FI/FD students? 3) Do FI students outperform FD students in the inductive group? Do FD students outperform FI students in the deductive group? The Group Embedded Figure Test was used to identify student cognitive styles. A self-designed test was conducted to realize student learning outcome. T-test, ANOVA, and descriptive statistics were applied to analyze the data. Results indicated that both approaches were effective, and the deductive group had more significant improvement. Next, both FI and FD students improved significantly, and FD student improvement was especially evident. Moreover, FD students in both groups improved more than FI students, but the difference was not significant.
\end{abstract}

Keywords: Inductive, Deductive, Field independent, Field dependent

\section{Introduction}

The growth or the decline of an approach to language teaching often depends on which language skills students need at that time. In the last two decades, the focus of language education has shifted from an analysis of language forms to authentic use of the target language. Many scholars advocate not only teaching students correct linguistic forms, but also when and how to use those appropriate forms to express their meanings in various situations (Ho, 2007).

The importance of grammar instruction has also gone through three stages: the prosperous stage (the first half of the twentieth century), the period of recession (1950-1960), and the period of revival (1980- to date). During the prosperous stage, the Grammar-Translation Method, which stresses linguistic analysis and translation ability, was the main approach to English teaching, especially in the study of Latin and Greek literature. With the passage of time, the increased contact among Europeans required English communication competence. English teaching methods changed to (e.g. the Direct Method) stressing English usage instead of mechanical grammatical drills and pattern practices. During World War II, people needed to learn the target language in a short time for military purposes. The Audio-Lingual Method, which focuses on the development of listening and speaking skills, became the tide of fashion. Thus, the importance of grammar teaching declined and teaching approaches (e.g. The Silent Way, Suggestopedia, Community Language Learning, and The Total Physical Response Method) disregarded teaching grammar rules. These approaches paid much attention to student communicational skills; however, student communication was grammatically inaccurate or insufficient. Therefore, after the 1980s, teaching approaches (e.g. the Communicative Approach) emphasized combining functions, meanings, and forms of English (Larsen-Freeman, 1986).

The recent trend of grammar instruction emphasizes the importance of meaningful practice and authentic communication. Instructors have applied teaching strategies that enhance structured input to direct the attention of students to sentences with the same structure, to raise student consciousness (Ellis, 2001; Fotos \& Ellis, 1991; Sharwood-Smith, 1993). For example, teachers first target a linguistic feature that is salient to students using underlining or italic fonts, and then ask students to use this target form in their communicative tasks. This method might awaken internalized grammatical knowledge of students to help them generalize structures on their own.

Some scholars (e.g. Ellis, 1999; McLaughlin, 1990; Van Patten, 1996) divide information processing of foreign language into three parts: input, processing, and output. Teachers who manipulate input of a target language (e.g. the 
salient structure with bold face in an article or slowed reading pace) make foreign language input more comprehensible for students. In their opinion, teaching activities should help students (1) pay attention to the target language input, (2) use their internal knowledge or interlanguage to comprehend the input, examine their speculations about structures and transfer the information, and (3) produce the target language, revise the mistakes, and learn the correct usage.

Because of the strong link between Input Processing Instruction and foreign language learning of students, which approaches could actually and effectively enable students to notice certain grammatical rules or features has been widely disputed. Among the different approaches for teaching grammar, deductive and inductive approaches have been among the most controversial issues in the field of language teaching $(\mathrm{Wu}, 2008)$. The deductive approach teaches grammar rules to learners by a very systematic method. In contrast, the inductive approach requests students to discover or infer grammar rules based on examples provided (DeKeyser, 1995).

In addition to the variables of proficiency level, the complicated level of sentence structures of the target language, and the similarity of L1 and L2, the cognitive styles of students might be another variable in the controversy over whether inductive or deductive approach is more effective. Among the various categories of cognitive styles, field independence (FI) and field dependence (FD) have been widely discussed. FI persons possess stronger analytical ability and self-confidence. They tend to learn on their own and like to compete with others. In contrast, FD persons like to observe other people, pay attention to the feelings of others, and possess better social skills. They prefer to cooperate with others and complete assigned tasks collaboratively (Witkin et al., 1962). Although controversy exists over the academic performance of FI/FD students in various school subjects, a number of studies support the idea that FI students outperform FD students in inductive instruction, and FD students benefit more from deductive instruction. FI students exhibit higher learning outcomes than FD students, no matter whether they receive instruction in the inductive or the deductive classroom (Abraham, 1985; Raschio, 1987; Thomas, 1987).

In 2005, the Ministry of Education in Taiwan declared that English education begins in the third grade. Thus, all students are required to study English in elementary school. The current Joint Examinations for Taiwanese High Schools and Universities are mainly in the format of grammatical tests. Therefore, many English teachers in Taiwan teaching under limited time constraints and in oversized classrooms adopt the deductive approach to teach English grammar, even though Western scholars have highly advocated an inductive approach.

Many Taiwanese English teachers prefer the deductive approach because it is very difficult for Chinese learners to understand English rules themselves. Some researchers attribute the difficulty to the following two facts. English and Chinese are two different language systems. For example, Mandarin does not include any tense markers; that is, Chinese is a language that does not morphosyntactically represent tense. To indicate the past tense or the future tense, Chinese use temporal adverbials such as 'Tso-Tien' (yesterday)' or 'Hsia Li Pai' (next week) and adverbs of frequency like 'I-Jing' (already) or aspectual particles like 'Le' to express the completion of an action (the perfect tense). Under the influence of Chinese interference, many Chinese students often misuse the simple present for the simple past or perfect form (Chou \& Wu, 2007). English is a complicated language. For example, English uses the past tense form to show politeness. A sentence such as, "Would you do me a favor?" does not express past time. Research findings reveal that verb tense errors are the most frequently committed errors for Chinese learners (Huang, 1994; Huang, 2006).

In addition to the problems of limited teaching time and a complicated English system, some studies indicate that Chinese students prefer the deductive approach. In Wang's study (2001), among 707 college students, 80\% of the FI and FD students preferred a teacher-centered approach, and only $20 \%$ of the students favored student-centered instruction.

Because of the unresolved conflict in empirical evidence, this research conducts communicative grammar instruction using the inductive/deductive approach separately in two freshmen classes, and then examines the effect of the two approaches on the FI/FD cognitive styles of students. More specifically, this study explores the following research questions: 1) What is the effect of the inductive and deductive approach on the learning outcomes of students learning English verb tenses? Which group has better performance? 2) What are the learning outcomes of field independent/dependent (FI/FD) students? Do the FI students significantly outperform the FD students? 3) How do inductive/deductive approaches and FI/FD cognitive styles create interactive effect on the learning outcomes of students? Do FI students outperform FD students in the inductive group? Do FD students outperform FI students in the deductive group?

To help readers understand the theoretical backgrounds of this study, the current research reviewed studies on the inductive/deductive approach to teaching grammar, the FI/FD cognitive style, the effect of matching FI/D with the 
inductive/deductive approach, and common English tense errors of Chinese learners.

\section{Literature Review}

\subsection{Inductive and Deductive Approach to Teaching Grammar}

The inductive and deductive approach has been widely studied in the field of second language acquisition. Erlam (2003) asserted that the deductive method to teaching grammar involves an explanation of grammar rules by the teacher before students participate in language practice. The method moves from general rule instruction to specific instances of language use. The inductive method emphasizes learning discovery, where students generalize rules from a large amount of underlying examples. The teacher functions as a counselor and presents grammar rules after students have already noticed the target features of the language through participating in tasks. Therefore, the inductive method moves from specific instances of language use to general rule explanation.

\subsubsection{Scholars' Views on Deductive Methods of Teaching Grammar}

The deductive method of teaching English grammar refers to the style of teaching students by introducing the grammatical rules first, and then applying them by the students. (Mohammed \& Jaber, 2008, p.545). This approach is similar to the grammar-translation method. Teacher explanation often dominates classroom activities, and student involvement and interaction is often minimized.

A few experimental studies support the view that deductive grammar teaching strategies are more beneficial to learners. For example, in the two studies of Scott $(1989,1990)$, subjects using a deductive approach exhibited significant improvement, while subjects using an inductive approach showed slight improvement. Scott suggested that an explicit grammar teaching strategy helps students quickly and effectively understand grammatical structures, and thus more class time can be devoted to practice activities. Furthermore, Erlam (2003) investigated 69 New Zealand high school students, who were learning direct object pronouns of French. The researcher divided the subjects into three groups: deductive group, inductive group, and control group. In the deductive group, the teacher explained the direct object pronouns and provided the sample sentences. Then students did some exercises, and the teacher corrected students' errors. In the inductive group, the teacher did not explain the rules of the target structure. Students were given a handout with pictures as well as statements, and the students were requested to match these statements to the pictures. Afterwards, an overhead projector presented some pictures, and two statements describing each picture were broadcasted. The students needed to decide which statement matched the picture. In the control group, students did not receive any target structure instruction. An immediate post-test and a delayed post-test were administered to the subjects. The results showed that the deductive group had significant better performance than both the inductive and the control groups on the two tests. Next, some studies conducted in Taiwan also demonstrated that the deductive approach was more efficient than the inductive approach in assisting student grammar learning. For example, in Lin's study (2007), he recruited 64 students from one elementary school in Taiwan. The subjects were assigned to either the inductive group or the deductive group and received a 12-week English verb tenses teaching, including the teaching of simple future tense, simple present tense, and simple past tense. In the inductive group, teacher did not explain the rules explicitly. Instead, students had to induce the rules from the materials with the target grammatical sentences and shared their findings with peers. In the deductive group, the teacher explained the rules directly, and asked students some related questions to check students' understanding of the grammatical rules. Two post-tests were used to measure student grammar comprehension achievements. Results indicated that the deductive group significantly outperformed the inductive group in acquiring grammar rules; however, no significant difference existed between the two groups of verb tense retention.

Another advantage of the deductive approach is that it prevents learners from consistently making the same errors. Some theorists (Boyle, 1994; Ruin, 1996) believe that if learners do not receive explicit instruction, their errors might fossilize in their interlanguage. Krashen (1985) and Terrell (1991) pointed out that when learners talk, they hear and process their own output. Thus, learner output inputs to the acquisition process. If the output is grammatical, then acquisition of the output will lead to increased grammatical speech. However, the output will be incorrect if the learner has not learned a rule correctly.

Some scholars (e.g. Ausubel, 1974; Higgs, 1985; Mohammed \& Jaber, 2008) suggested that teacher instruction speeds up the acquisition process of adult language learners. They criticized that only gifted students are capable to generalize the rules from examples, and that most average students need teacher guidance to help them confirm, modify, or add new rules to their innate hypothetical rules.

Terrell (1991) similarly contended that explicit instruction helps learners make sense of individual words in input utterances, and also draws their attention to specific language structure. In their opinion, when learners know little about the target language, it is very difficult for them to understand non-salient grammatical, meaning-forming 
relationships, such as participles and inflections.

Mohammed (1993), citing Gass (1991), stated that "Explicit grammar teaching makes learners aware of the discrepancies between what they themselves have constructed for their second language and the system which becomes apparent to them for the target language data they are confronted with. In other words, it acts as a selective attention device" (p. 59).

Some researchers (Carr \& Curran, 1994; Shanks \& St. John, 1994) believe that an inductive approach might only be effective for teaching relatively simple grammatical structures. In their opinion, some complicated rules are difficult for learners to master unconsciously.

\subsubsection{Scholars' Views on Inductive Grammar Methods of Teaching Grammar}

The inductive approach refers to the style of introducing language context containing the target rules where students can induce such rules through the context and practical examples. In other words, the sequence in this approach goes from creating a situation and giving examples to the generalization where students should discover such generalization by themselves or with the teacher's help. (Mohammed \& Jaber, 2008, p.546)

Experimental studies both in western countries and in Taiwan have shown that inductive grammar teaching strategies are more beneficial to learners. For example, Herron and Tomasell (1992) compared the learning of French grammatical structures by 26 beginning level American college students in the guided induction and deduction teaching conditions. In the guided induction teaching, the teacher first gave students some contextualized oral drills, and students induced for themselves the underlying grammatical rules. Then the students were requested to complete a model sentence on the board with structure equivalent to the ones practiced orally. Thus, students could check their hypotheses to the target structure were correct or not. On the other hand, in the deduction teaching condition, the teacher stated the rule and illustrated it with a written model. After that, students practiced the rules through some contextualized oral drills. As to the studies conducted in Taiwan, Wang (2002) investigated 81 senior high school Taiwanese students' performance in learning collocation patterns. Her study revealed that the inductive group improved more significantly than did the deductive group, especially in the condition of easy patterns. As to the difficult patterns, there were no significant differences between the two groups.

Although some deductive advocates assume that the inductive approach is too difficult for weak students (e.g. Ausubel, 1974; Carroll, 1964), Shaffer (1989) argued that the inductive approach is valuable for all levels of students, but especially for weak students. In his study, Shaffer chose three structures for the French class and four structures for the Spanish class. These structures were chosen because the concepts of the structures do not exist in English, and because they are considered difficult to learn. The subjects of this study were 319 students from three different high schools, who were divided into inductive group and deductive group. His study findings showed that the inductive groups of all ability levels scored higher for all structures than the deductive students, but the difference did not achieve significant level. Next, the weak students benefited most from using the inductive presentation.

Shaffer's study (1989) not only confirmed the finding of the cognitive psychologist Bruner (1961) that "Students do better when having to discover underlying patterns themselves rather than being told about them" (Shaffer, p. 400), but also provided evidence that the inductive approach can be used to teach difficult structures.

Another benefit of using the inductive approach is that it increases the motivation of students to study L2. Some study findings (e.g., Swaffar \& Woodruff, 1978) also show this tendency.

The deductive approach has received much criticism from the perspective of cognitive psychology, which stresses that learners should actively contribute to their own learning.

Piaget (1974) claimed that learners need to be involved in the interaction between their innate structures of the mind and the outside learning environment. Piaget suggested that rote memory cannot be equated with comprehension. He asserted that if students fail to comprehend the meaning underlying numerous linguistic structures and transform them into internalized intake, then those structures are meaningless and cannot become instinctual for later use. In his opinion, when people discover underlying patterns for themselves, the learned knowledge lasts longer in human memory.

Garrett (1989) criticized that although the deductive approach may offer explanations of linguistic rules, it does not help students connect the form with the meaning in their cognitive mechanism. For Garrett, "The separation of form and meaning is not only impossible in terms of all that we know about the nature of language knowledge and language use, but also counter-productive in terms of our philosophical goal of helping students express their own meaning in the appropriate forms of the target language" (p. 24). 
In sum, the results of previous studies on effectiveness of the deductive or inductive approach are mixed and inconclusive. Many researchers (e.g., Celce-Murcia, 1985) suggest that the cognitive styles of students may influence the effectiveness of a particular teaching method. For example, research from a variety of educational fields supports the view that inductive instruction enhances the achievement of field independent (FI) students, whereas field dependent (FD) students are more likely to succeed with deductive instruction (Andrews, 1984; Hansen \& Stansfield, 1982a).

\subsection{Scholars' Views on the Effect of Field Dependent /Independent Cognitive Styles}

Witkin et al. (1977) proposed that field dependence (FD) indicates a tendency to rely on external frames of reference in cognitive activities, whereas field independence (FI) suggests reliance on internal rules or strategies for processing information. Chapelle and Green (1992) stated that, "The FI person is analytic, confident, and self-reliant, whereas the field dependent person is holistic, uncertain, and dependent upon others" (p. 49).

Some researchers (e.g. Keefe, 1991; Messick et al., 1976; Witkin, 1976) believe that cognitive styles are relatively stable traits in adults, while others (e.g. Brown, 2007; Fourier, 1984; Hoffman, 1997; Reid, 1987) support the possibility of 'style-shifting.' In Keefe's opinion, "Learning style is a relatively stable indicator of how learners perceive, interact with, and respond to the learning environment" (p. 3). Messick et al. also claimed that learner cognitive styles persist regardless of changes in instructional content. However, Hoffman suggested that some persons could be 'mobile learners,' i.e., those who appear to be both independent and dependent at the same time. Fourier found that mature students could learn to adjust to instructor cognitive styles. Brown suggested that a bi-cognitive person might be more successful in learning.

Although some conflict exists in research findings on the relationship between FI/FD cognitive style and second language learning achievement, many researchers have found that FI learners achieve better in most language tests. For example, Jamieson (1992) showed that FI learners scored higher on TOEFL than FD learners. However, Barnwell (1992) revealed that while FI students demonstrated higher grammatical competence, their communicative competence did not exceed that of FD students. Barnwell suggested that FD students would score higher on global tests.

Mahlios (1978) suggested that particular traits of FI/FD learners might be more or less effective for specific tasks or situations. Similarly, Brown (1980) believed that the effect of FI/FD on language learning might depend on the task and context. In his study of adult ESL learners, Brown (1977) found that FD learners possess quite high language proficiency. He explained that since these FD students tend to be more socialized, empathetic, and sensitive to the feelings and thoughts of others, they could more easily acquire English in an English-speaking environment (a natural setting) through communication with others. As for FI learners whose achievement in the classroom correlated positively with their standardized tests (Tucker et al., 1976), Brown explained that the analytical skill of FI students helps them successfully perform analytical tasks in the classroom such as drills and grammar cloze tests.

Hansen and Stansfield (1982b) supported the explanation of Brown regarding the analytical skills of FI learners. They found that a cloze test requires the student to fill in the appropriate word in the blank using a hypothesis-testing strategy, a skill possessed by an FI person, but not by an FD person, who tends to have difficulty analyzing information to solve a problem.

In sum, research findings focusing on the relationship between FI/D learning style and language achievement are inconclusive.

\subsection{Scholars' Views on the Effect of Combined Variables: Matching FI/D with the Inductive/Deductive Approach}

Many studies show a significant effect from matching FI/D cognitive styles to inductive/deductive modes of instruction (Andrews, 1984; Douglass, 1978; Hansen \& Stansfield, 1982b). However, most of these studies deal with physics, biology, or mathematics, rather than language learning. Some studies (Abraham, 1985; Horak, 1978) even observe a contradiction in the finding that FD students perform better under the inductive method.

Thomas's study (1987) indicates another mixed finding, where he reported that FI students are capable of achieving "well" with either the deductive or inductive teaching method. However, FD students have difficulty with the inductive method. His finding suggests the importance of considering FD students when presenting a lesson inductively.

Considerable mixed and conflicting evidence exists among the rare studies on the relationship of FD/I and the deductive/inductive teaching method in language classes (Abraham, 1985; Raschio, 1987; Thomas, 1987). For example, Raschio's study shows no significant relationship between the cognitive style of learning and the teaching 
method, and although FI learners generally scored higher than FD learners on achievement tests, the results did not reach a significant level. The comparative teaching methods in the Raschio study were used in computer instruction and traditional language instruction rather than in the deductive and inductive approach. Similarly, findings from the Abraham study and the Thomas study cannot be generalized for the regular classroom situation, since their studies were conducted in a computer classroom.

Some researchers have suggested that other variables such as gender, length of time in studying English, level of education, and cultural traits might affect the relevance of FD/I learning styles to foreign language achievement. The study of Naiman et al. (1978), for example, indicates that the FD/I factor is more important in advanced stages of language learning.

Literature on the teaching and learning styles of the Chinese is rare. Research that investigates the match between deductive/inductive teaching methods and the cognitive styles of Chinese students is even more limited, and unfortunately, the results of these studies are controversial. For example, in Chang's study (2005), two classes of 44 senior high school students received one semester of grammar instruction using subjective and indirect questions. The findings show that the inductive group performed better in the post-test than the deductive group. The inductive group showed a more positive attitude toward their English learning than the deductive group did. The Shih (2008) study included 70 junior high school students learning relative English clauses. Although there was no significant difference between the inductive and the deductive group, high-achievers benefited more from the deductive approach than from the inductive approach. High-achievers significantly outperformed their mid- or low-ability counterparts in inductive instruction. Interestingly, findings from another study (Liu, 1999) differ from Shih's study. The subjects of the Liu study were also junior high school students learning English clauses, but the findings showed an interactive effect of cognitive style and learning approaches. FI students outperformed FD students in the inductive group and FD students outperformed FI students in the deductive group on tasks identifying English clauses.

\subsection{Common English Tense Errors of Chinese Students}

Chou and $\mathrm{Wu}$ (2007) stated, "Tense locates an event or a situation in time with respect to the moment of speaking (speech time) or a reference point (reference time); aspect manifests the temporal constituency (the internal temporal status) of a situation (p.32)". In most recent approaches many scholars agree that in English there are two tenses: the present tense and the past tense. Aspect further describes continuation, duration, repetition, and completion of events. For example, simple past tense, past perfect tense, and past progressive tense manifest a distinction in aspect. Many scholars (e.g. Bardovi-Harling \& Reynolds, 1995; Robison, 1995; Yu, 1997) treat tense and aspect as an integrated whole. Based on this perspective, English consists of twelve verb tenses.

Several researches show that Chinese students often commit English verb tense errors in their discourse and written production (Huang, 2006; Huang, 1994). Because Chinese language does not add inflectional affixes to verbs to convey temporal relationships, many Chinese students tend to avoid the progressive and perfect aspects (Chou \& $\mathrm{Wu}$, 2007). Chinese students frequently misuse auxiliary verbs, use redundant auxiliary verbs, or even omit the be verb in the progressive aspect. For example, "I didn't (wasn't) happy yesterday." "She is watches (watches) TV every day." "He running (is running)." They might ignore the auxiliary and create negatives and questions from full forms: "They study not," or "They not study." They frequently misspel the irregular past verb and past participle such as "sleeped (slept)", or "goed (went, gone)" (Chiou, 2008).

Because little research has been done on the effect of the deductive/inductive approach on FI/FD Chinese college students learning English verb tenses, the most difficult grammatical rules for Chinese learners, this study provides more information regarding the possible role of the FD/I variable in foreign language learning.

\section{Methodology}

\subsection{Subjects}

One hundred English major freshmen at the university of the researcher were quasi-randomly selected as the subjects of this study. These participants, who had intermediate English proficiency level, were drawn from two Freshman English Grammar classes. Class A consisted of 51 students, and Class B consisted of 49 students. The ratio of boys to girls was approximately 1:6. Each class was randomly assigned to the inductive or the deductive approach by flipping a coin. As a result, Class A received deductive instruction, and Class B received inductive instruction.

\subsection{Instruments}

The first instrument was a self-designed English tense comprehension test based on the teaching materials in the two 
textbooks, "Understanding and using English grammar" by Betty Schrampfer Azar, and "Grammar in context" by Sandra N. Elbaum. This comprehension test was used as the pre/post test of the study, and was designed to find out how well students understand the twelve English tenses before and after receiving the experimental grammar instruction. The test consisted of 48 questions, and each tense was examined by four questions (See Appendix). The full test score was 96 ( 2 points per question). Two English professors were invited to evaluate the content validity of the test. Because the comprehension test content was similar to the content of the English Entrance Examination for the Taiwanese Technical University (EEE), the previous test scores of subjects on the EEE were used as criterion-related evidence of validity in examining the comprehension test scores. The Pearson Correlation Coefficient was set at 0.05 , and the statistic result showed acceptable validity $(\mathrm{p}<0.01)$ for the test.

The second instrument was the Group Embedded Figures Test (GEFT), developed by Witkin and his colleagues in 1971. GEFT is currently the most popular instrument used to determine the field dependent/independent (FD/FI) cognitive style (Liao, 2007). This test asks people to find a simple figure hidden in a complex design. The test assumes that FI people are capable of separating an item (e.g., a rod) from an organized field (e.g., a frame) and expects them to easily locate the simple figure in the complex design, while FD people have difficulty separating the simple figure from the complex design. Based on cognitive theory and empirical evidence, the GEFT test is regarded as a good instrument with good reliability $(\mathrm{r}=0.82)$ and construct validity (Goodstein, 1978).

\subsection{Data Collection Procedures}

The subjects took the pre-test, so the researcher could record student comprehension about English tenses prior to the experimental instruction. The subjects also took the GEFT to determine their individual cognitive style. Next, the researcher conducted the deductive/inductive English grammar instruction with the aid of multimedia to Class A/B respectively for two months. The subjects took the post-test after the experimental teaching. Finally, the researcher and her colleague scored the pre-test, post-test, and GEFT with the same scoring criterion, to enhance rater reliability.

\subsection{Communicative Grammar Instruction through Technology}

To prepare students for using English in real contexts, the teacher-researcher adopted the communicative approach to teach twelve English tenses (simple present, present progressive, present perfect, present perfect progressive, simple past, past progressive, past perfect, past perfect progressive, simple future, future progressive, future perfect, and future perfect progressive). Both groups of students participated in communicative written and oral practice. This approach anticipated that students would not only be equipped with grammar knowledge, but also understand when and how to appropriately apply learned knowledge in various communication settings.

Both deductive/inductive instructions were conducted in the same computer lab classroom. Most of the materials presented in class were electronic files such as Word documents, Power Point files, and CD/CD-ROM programs. The teacher utilized different colors, bold type, and underlining to emphasize the main points of the lesson to raise student consciousness of various visual and audio inputs and to reinforce language learning. The difference of deductive/inductive instruction lies in how the teaching materials (input processing) are arranged and how those materials raise student consciousness. Deductive instruction begins with teacher explanation, of grammar rules, followed by students engaging in language practice. In contrast, inductive instruction requires students to generalize and verbalize the rules from grammatical structure used in context.

\subsubsection{Inductive Communicative Grammar Instruction}

The procedure for conducting inductive grammar instruction is as follows. (1) The teacher used PPT files on the computer to introduce several sentences or model articles containing the same target tense features. The target tense structures were marked in different colors or were underlined. (2) Students read those sentences and generalized the rules for that target tense. (3) The teacher chose some students to report their answers. (4) The whole class discussed whether answers from their peers were correct or not. (5) The teacher concluded the student discussion and explained in detail about target tense usage. (6) Students were involved in oral communicative practice and written exercises, playing games, and listening to English songs related to the target tense.

\subsubsection{Deductive Communicative Grammar Instruction}

The procedure for conducting the deductive grammar instruction is as follows. (1) The teacher used PPT files on the computer to explain the target tense features. The target tense forms in the example sentences or model articles were marked in different colors or were underlined. (2) Students participated in communicative practice and written exercises, played games, and listened to English songs to practice the target tense. 


\subsection{Data Analysis}

After collecting data from the GEFT, and the pre- and post-test, the researcher used a paired t-test and an independent t-test to answer the first research question. Next, the researcher used descriptive statistics, an independent t-test, a paired t-test, and ANOVA to answer the second research question. An independent t-test, a paired t-test, and ANOVA were used to answer the third research question

To evaluate student cognitive styles, this research used one-half of a standard deviation above or below the mean (mean $=12.34,0.5 \mathrm{SD}=1.865$ ) as the cutoff score of FI/D. The middle distribution of the test was discarded, which means the participants whose test score was within one-half of a standard deviation above or below the mean were not counted. Only those upper and lower participants, easily identified as either FI or FD persons were counted. In this way, the GEFT scores of FI persons were within 14-18, and the scores of FD persons were within 0-10. Students whose scores were within 11-13 were regarded as field neutral students and were excluded from the subjects in this analysis.

\section{Results and Discussion}

\subsection{The Effect of Inductive/Deductive Approaches on Student Learning Outcomes}

Table 1 reveals no significant comprehension difference between the inductive and deductive group before subjects received English verb tense instruction; however, the mean score of the deductive group is slightly lower than the inductive group. In contrast, a significant difference between these two groups in student performance after receiving grammar instruction, and the deductive group still outperformed the inductive group $(p<0.01)$. It is clear that students in the deductive group improved more significantly than the inductive group $(\mathrm{p}<0.001)$, although both groups improved significantly, regardless of the teaching approach (See Table 2).

The deductive approach seems a more effective method to teach English verb tenses for Chinese learners. This result echoes Wang's finding (2001) that Chinese students prefer the deductive approach. The finding also confirms previous research (e.g. Fischer, 1979; Robinson, 1994) suggesting the inductive approach when L1 sentence structures were similar to those of L2; however, a deductive approach would be necessary when target language structures differed from the native language of learners or when the target rules were very complex.

\subsection{Learning Outcomes of Field Independent/ Dependent Students}

As mentioned above, subjects who scored one-half of a standard deviation above the mean on the GEFT were classified as FI learners. Those who scored one-half of a standard deviation below the mean were classified as FD learners. As a result, there were 23 field dependent students (45.1\%), 14 field independent students (27.5\%), and 14 field neutral students (27.5\%) in the deductive group. In the inductive group, there were $20 \mathrm{FD}(40.8 \%)$ students, 13 FI students (26.5\%), and 16 FN students (32.7\%)

Table 3 indicates that FI slightly outperformed FD students before the study, although the pre-test scores of both groups were not very high. However, after two months of instruction, FD students exhibited enhanced post-test scores compared to those of FI students. Unexpectedly, FD students demonstrated higher learning outcomes than FI students, although the difference was not significant.

Table 4 shows that the difference between the pre-test score and the post-test score was remarkably significant for both FI and FD learners $(p<0.001)$. That is, no matter what types of instructions they received, both FI and FD learner comprehension of English verb tenses significantly improved, and FD student improvement was even greater than that of FI students.

These findings suggest that communicative grammar instruction is effective to help Chinese learners learn English verb tense rules and usages. It is also reasonable to infer that FD students would especially benefit from communicative grammar instruction. One possible explanation for this is that FD students tend to be socially oriented and more willing to communicate with others (Brown, 2007). Because of their personal learning trait, FD students are apt to learn well when they are involved in interacting with others. In contrast, FI students might not be accustomed to collaborative tasks, since they prefer to work individually. Consequently, they may be less interested in communicative practice.

\subsection{The Interactive Effect of Inductive/Deductive Approaches and FI/FD Cognitive Styles on Student Learning Outcomes}

Table 5 shows enhanced performance of FI students in English verb tenses than FD students in both teaching groups before the study, however, the difference was not significant. After instruction, FI students continued to outperform FD students in the deductive group; nevertheless, FD students surpassed FI students in the inductive group. This 
finding is surprising, as it partly contradicts previous studies suggesting that FI students learn better under inductive instruction and FD students benefit more from deductive instruction (Liu, 1999). As the Shih study (2008) points out, higher-level students gained more from the deductive approach than from the inductive approach. In this study, FI students appeared to be higher proficiency learners before the study; therefore, the deductive approach might be more appropriate for them.

Furthermore, it is interesting to find that FD students, no matter whether they were in deductive group or inductive group, improved more than FI students. This is consistent with earlier findings in the previous section revealing that FD persons were more successful learners under the communicative approach due to the fact that they preferred more personal interaction.

Finally, Table 6 summarizes the interactive effect of inductive/deductive approaches and FI/FD cognitive styles on student learning outcomes. It is possible that the match or mismatch of field dependent/independent cognitive style and deductive/inductive teaching approach did not significantly influence student learning, but by other variables such as student interest, motivation, and needs. Although this intriguing possibility needs further investigation, the findings of this study imply that the communicative approach is especially beneficial for FD learners because diverse communicative activities in this approach meet student needs and learning preferences.

\section{Conclusions}

This study examined factors such as inductive/deductive teaching strategies, student cognitive styles, and the effect of matching inductive/deductive methods with field independent/dependent (FI/FD) styles related to grammar instruction within a communicative approach in Taiwan.

The inductive approach is currently more popular for teaching grammar and widely recommended by Western scholars (e.g., Brown, 2007); however, the present study found that while both groups exhibited remarkable improvement after two months of instruction $(\mathrm{p}<0.001)$, students in the deductive group improved more significantly than the inductive group $(\mathrm{p}<0.001)$. This result implies that explicit instruction of grammatical rules is the most efficient way to learn English for most Chinese learners. Two reasons might account for this finding. First, the Confucian tradition has trained Chinese students to be docile learners in the classroom. Therefore, they may feel insecure to discover English rules by themselves. Thus, the factor of culture may play a very important role in discussing the effect of foreign language learning. Secondly, it is difficult for Chinese learners to distinguish and generalize English grammatical features, since English sentence structures are different from Chinese structures.

The second finding of the study is that both FI and FD learners' comprehension of English verb tenses significantly improved $(p<0.001)$, and the improvement of FD students was greater than that of FI students, although the difference was not significant $(\mathrm{p}<0.05)$. This finding suggests that communicative grammar instruction is beneficial to Chinese students of different cognitive styles, but the effect may be especially significant among FD students. Because FD students are more likely to be interested in interpersonal communication, they may be more accustomed to the communicative approach, which requires them to learn grammar during oral or written discourse in English.

The third result of this study, regarding the interactive effect of teaching approaches and cognitive styles on the learning outcomes of students, is quite unexpected, because it partially contradicts previous studies. The Liu (1999) study, for example, showed that FI students in the inductive group learned better than FD students and FD students benefited more from deductive instruction than FI students. However, the finding of the present study indicates that while FI students in the deductive group outperformed FD students in the post-test, FD students surpassed FI students in the inductive group. Further, FD students in both groups improved to a greater degree than FI students did, although the difference was not significant. This finding implies that matching deductive/inductive teaching strategies with FD/FI learners may not significantly influence student-learning achievement in a communicative grammar classroom. Additional variables such as the type of achievement tests, the English proficiency level of students, or learner motivation might affect the relevance of field dependent/independent cognitive style to student learning achievements.

Since most studies on the deductive/inductive approaches and FI/FD cognitive styles were carried out in other disciplines, this study is relatively new and original. Future research could examine these variables to determine the effect of cognitive styles on Chinese learners.

\section{Acknowledgements}

Part of this paper was presented in the CLaSIC 2010 International Conference, December 2-4, 2010. Centre for Language Studies, National University of Singapore. The author would like to express her gratitude to the audience for their remarkable suggestions. 


\section{References}

Abraham, R. G. (1985). Field independence-dependence and the teaching of grammar. TESOL Quarterly, 20 (4), 689-702. http://dx.doi.org/10.2307/3586671

Andrews, J. D. (1984). Discovery and expository learning compared: Their effects on independent and dependent students. Journal of Educational Research, 78 (2), 80-89.

Ausubel, D. P. (1974). Adults vs. children in second-language learning. The Modern Language Journal, 58, $420-423$.

Bardovi-Harling, K., \& Reynolds, D. W. (1995). The role of lexical aspect in the acquisition of tense and aspect. TESOL Quarterly, 29, 107-131. http://dx.doi.org/10.2307/3587807

Barnwell, D. (1992). Applications of foreign language aptitude and learning style research. Paper read at Central States Conference on Language Teaching. $\quad$ (ERIC Document Reproduction Service No. ED 364075).

Boyle, E. M. (1994). This is the dictionary of Ivan Petrovich: Balancing the role of grammar in the Russian communicative classroom. Theory into Practice, 33 (1), 10-15. http://dx.doi.org/10.1080/00405849409543609

Brown, H. D. (1977). Cognitive and affective characteristics of good language learners. Paper presented at the Los Angeles Second Language Forum, Los Angeles, CA. (ERIC Document Reproduction Service No. ED 184381).

Brown, H. D. (1980). Principles of language learning and teaching. Englewood Cliffs, NJ: Prentice-Hall.

Brown, H. D. (2007). Principles of language learning and teaching( $\left.5^{\text {th }}\right)$. NJ: Pearson Education.

Bruner, J. S. (1961). The act of discovery. Harvard Educational Review, 58, 420-423.

Carr, T. H., \& Curran, T. (1994). Cognitive factors in learning about structured sequences: Applications to syntax. Studies in Second Language Acquisition, 16, 205-230. http://dx.doi.org/10.1017/S0272263100012882

Carroll, J. B. (1964). Language and thought. Englewood Cliffs, NJ: Prentice-Hall.

Celce-Murcia, M. (1985). Making informed decisions about the role of grammar in language teaching. Foreign Language Annals, 18 (4), 297-301. http://dx.doi.org/10.1111/j.1944-9720.1985.tb01807.x

Chang, S. H. (2005). A comparative analysis of two approaches to grammar teaching: Constructive vs. lecturing (Unpublished master's thesis). National Kaohsiung Normal University, Taiwan.

Chapelle, C., \& Green, P. (1992). Field independence/dependence in second language acquisition research. Language Learning, 42, 47-83. http://dx.doi.org/10.1111/j.1467-1770.1992.tb00700.x

Chiou, M. H. (2008). An analysis of tense errors by junior high school students (Unpublished master's thesis). National Kaohsiung Normal University, Taiwan.

Chou, M. C. \& Wu, K. H. (2007). The temporal system of interlanguage of college EFL learners in Taiwan. Hua-Kang English Journal, 13, 29-57.

Dekeyser, R. M. (1995). Learning second language grammar rules. Studies in SecondLanguage Acquisition, 17, 379-410. http://dx.doi.org/10.1017/S027226310001425X

Douglass, C. B. (1978). Effects of field dependent-independent instructional sequence on high school biology. Paper presented at the annual meeting of the National Association for Research in Science Teaching. Toronto, Canada. (ERIC Document Reproduction Service No. ED 167352).

Ellis, R. (2001). Introduction: Investigating form-focused instruction. Language Learning, 51 Supplement, 1-46. http://dx.doi.org/10.1111/j.1467-1770.2001.tb00013.x

Ellis, R. (1999). Cognitive approaches to SLA. Annual Review of Applied Linguistics, 19, 22-42. http://dx.doi.org/10.1017/S0267190599190020

Erlam, R. (2003). The effects of deductive and inductive instruction on the acquisition of direct object pronouns in French as a second language. The Modern Language Journal, 242-260. http://dx.doi.org/10.1111/1540-4781.00188

Fischer, A. R. (1979). The inductive-deductive controversy revised. The Modern Language Journal, 63, 98-105. http://dx.doi.org/10.1111/j.1540-4781.1979.tb02433.x

Fotos, S., \& Ellis, R. (1991). Communicating about grammar: A task-based approach. TESOL Quarterly, 25, 605-628. http://dx.doi.org/10.2307/3587079

Fourier, M. J. (1984). Disclosure of cognitive style information: Effects on achievement of adult learners. Adult 
Education Quarterly, 34, 147-154. http://dx.doi.org/10.1177/0001848184034003003

Garrett, N. (1989). The role of grammar in the development of communicative ability. Applied Language Learning, 1 (1), 15-32.

Gass, S. (1991). Grammar instruction, selective attention and learning processes. In R. Philipson, E. Kellerman, L. Selinker, M. Sharwood-Smith, \& M. Swain (Eds.), Foreign/second language pedagogy research (pp. 134-141). Clevedon, UK: Multilingual Matters.

Goodstein, L. (1978). Group embedded figures test: A review. In Oscar K. Buros (Ed.), the eighth mental measurements yearbook (Vol. 1) (pp. 837-838). Highland Park, NJ: Gryphon.

Hansen, J., \& Stansfield, C. (1982 a). Field dependence-independence as a variable in second language cloze test performance. Paper presented at the International Conference of Teachers of English to Speakers of Other Languages. Honolulu, HI. (ERIC Document Reproduction Service No. ED 215585).

Hansen, J., \& Stansfield, C. (1982 b). Student-teacher cognitive styles and foreign language achievement: A preliminary study. The Modern Language Journal, 66(3), 263-273. http://dx.doi.org/10.1111/j.1540-4781.1982.tb06988.x

Herron, C., \& Tomasello, M. (1992). Acquiring grammatical structures by guided induction. The French Review, 65 (5), 708-718.

Higgs, T. V. (1985). Teaching grammar for proficiency. Foreign Language Annals, 18 (4), 289-296. http://dx.doi.org/10.1111/j.1944-9720.1985.tb01806.x

Ho, S. C. (2007). Effects of using contrastive context in teaching English tense-aspect (Unpublished master's thesis). National Chin-Hwa University, Taiwan.

Hoffman, S. Q. (1997). Field dependence/independence in second language acquisition and implications for educators and instructional designers. Foreign Language Annals, 30 (2), 222-234. http://dx.doi.org/10.1111/j.1944-9720.1997.tb02344.x

Horak, V. (1978). The effects of inductive-deductive teaching methods and field-dependence-independence cognitive style on student achievement in mathematics. Paper presented at the annual meeting of the National Council of Teachers of Mathematics. SanDiego, California. (ERCI Document Reproduction Service No. ED 161700).

Huang, H. S. (1994). An analytic study on tense errors committed by Chinese learners of English in southern Taiwan (Unpublished master's thesis). National Kaohsiung Normal University, Taiwan.

Huang, Y. M. (2006). Learners' tense awareness and error analysis of English interrogatives by EFL junior high students in Taiwan (Unpublished master's thesis). National Kaohsiung Normal University, Taiwan.

Jamieson, J. (1992). The cognitive styles of reflection/impulsivity and field independence/dependence and ESL success. The Modern Language Journal, 76, 491-501. http://dx.doi.org/10.1111/j.1540-4781.1992.tb05398.x

Keefe, J. W. (1991). Learning style: Cognitive and thinking skills. Reston, VA: National Association of Secondary School Principals.

Krashen, S. D. (1985). The input hypothesis. London: Longman.

Larsen-Freeman, D. (1986). Techniques and principles in language teaching. New York: Oxford University Press.

Liao, H. C. (2007). The relationship between student-teacher cognitive styles and students' English performance in junior high school (Unpublished master's thesis). National Chengchi University, Taiwan.

Lin, M.H. (2007).The effects of the inductive and deductive approaches on elementary school students' English grammar acquisition (Unpublished master's thesis). Chaoyang University of Technology, Taiwan.

Liu, P. H. (1999). A study of the effect of cognitive styles learning approaches on identifying English clause tasks (Unpublished master's thesis). National Kaohsiung Normal University, Taiwan.

Mahlios, M. C. (1978). Implications of cognitive style for teachers and learners. (ERIC Document Reproduction Service No. ED 152704).

McLaughlin, B. (1990). Theories of second language acquisition. London: Edward Arnold.

Messick, S., \& Associates. (1976). Individuality in learning ( $1^{\text {st }}$ ed.). San Francisco: Jossey-Bass.

Mohammed, A. M. (1993). Towards a learner-centered technique of teaching grammar. Language Learning Journal, 
7, 59-63. http://dx.doi.org/10.1080/09571739385200171

Mohammed, A. A., \& Jaber, H. A. (2008). The effects of deductive and inductive approaches of teaching on Jordanian University students' use of the active and passive voice in English. College Student Journal, 42( 2), $545-553$

Naiman, N., Frohlich, M., Stern, H. H. \& Todesco, A. (1978). The Good Language Learner. Toronto: Modern Language Centre, Ontario Institute for Studies in Education.

Piaget, J. (1974). The future of developmental children psychology. Journal of Youth and Adolescence, 3 (2), 87-94. http://dx.doi.org/10.1007/BF02215168

Raschio, R. A. (1987). The effects of the presentation of Spanish CAI lessons on field dependent/independent college students of beginning college students of beginning Spanish (Unpublished doctoral dissertation). University of Minnesota, Minneapolis, MN.

Reid, J. M. (1987). The learning style preferences of ESL students. TESOL Quarterly, 21 (1), 87-111. http://dx.doi.org/10.2307/3586356

Robinson, P. (1994). Computers, corpora and language. The Teacher Trainer, 8, 3-8.

Robinson, R. E. (1995). The aspect hypothesis revisited: A cross-sectional study of tense and aspect marking in interlanguage. Applied Linguistics, 16, 344-370. http://dx.doi.org/10.1093/applin/16.3.344

Ruin, I. (1996). Grammar and the advanced learner: On learning and teaching a second language. Stockholm: Almqvist \& Wiksell.

Scott, V. M. (1990). Explicit and implicit grammar teaching strategies: New empirical data. The French Review, 63 (5), 779-789.

Scott, V. M. (1989). An empirical study of explicit and implicit teaching strategies in French. The Modern Language Journal, 73, 14-22. http://dx.doi.org/10.1111/j.1540-4781.1989.tb05303.x

Shaffer, C. (1989). A comparison of inductive and deductive approaches to teaching foreign languages. The Modern Language Journal, 73, 395-403. http://dx.doi.org/10.1111/j.1540-4781.1989.tb05319.x

Shanks, D. R., \& St. John, M. F. (1994). Characteristics of dissociable human learning systems. Behavioral and Brain Sciences, 17, 367-395. http://dx.doi.org/10.1017/S0140525X00035032

Sharwood-Smith, M. (1981). Consciousness-raising and the second language learner. Applied Linguistics, 2, 159-169. http://dx.doi.org/10.1093/applin/2.2.159

Sharwood-Smith, M. (1993). Input enhancement in instructed SLA. Studies in Second Language Acquisition. 15, 165-179. http://dx.doi.org/10.1017/S0272263100011943

Swaffar, J. K., \& Woodruff, M. S. (1978). Language for comprehension: Focus on reading: A report on the University of Texas German Program. The Modern Language Journal, 60, 27-32.

Shih, J. Y. (2008). Effects of inductive and deductive approaches in grammar instruction for junior high school students of differing English proficiency (Unpublished master's thesis). National Pingtung institute of commerce, Taiwan.

Terrell, T. D. (1991). The role of grammar instruction in a communicative approach. The Modern Language Journal, 75 (1), 52-63. http://dx.doi.org/10.1111/j.1540-4781.1991.tb01083.x

Thomas, A. C. (1987). The effects of inductive and deductive teaching strategies in computer-based language lessons on the performance of high school students identified as being field-dependent or independent (Unpublished doctoral dissertation). The Ohio State University. Columbus, $\mathrm{OH}$.

Tucker, G. R., Hamayan, E., \& Genesee, F. H. (1976). Affective, cognitive and social factors in second language acquisition. The Canadian Modern Language Review, 32, 214-226.

Van Patten, B. (1996). Input processing and grammar instruction in second language acquisition. Norwood, NJ: Ablex.

Wang, L. Y. (2002). Effects of inductive and deductive approach on EFL learning collocation patterns by using concordancers (Unpublished master's thesis). National Yunlin University of Science and Technology, Taiwan.

Wang, P. L. (2001). The impact of cognitive styles on technical colleges students' English teaching method preferences. Journal of National Kaohsiung University of Applied Sciences, 31, 479-510. 
Witkin, H. A. (1976). Cognitive style in academic performance and in student-teacher relations. In S. Messick (Ed.), Individuality in learning (pp. 38-72). San Francisco: Jossey-Bass.

Witkin, H. A., Dyk, R. B., Hanna, F. F., Goodenough, D. R., \& Karp, S. A. (1962). Psychological differentiation. New York: John Wiley.

Witkin, H. A., Moore, C. A., Goodenough, D. R., \& Cox, P. W. (1977). Field dependent and field independent cognitive styles and their educational implications. Review of Educational Research, 47, 1-65.

Witkin, H. A., Oltman, P., Raskin, E. and Karp, S. (1971). A manual for the embedded figures tests. Palo Alto, Calif.: Consulting Psychologists Press, Inc.

Wu, M. J. (2008). Principal approaches of grammar instruction. US-China Foreign Language, 6 (11), 29-35.

Yu, H. (1997). A study on the use of English tense-aspect forms in narrative compositions by Taiwan college students and its pedagogical implication (Unpublished doctoral dissertation). National Taiwan Normal University, Taiwan.

Table 1. Students' Test Difference between Groups (Independent t-test)

\begin{tabular}{|c|c|c|c|c|c|c|c|c|c|c|c|c|c|}
\hline \multirow[t]{2}{*}{ Class } & \multirow[t]{2}{*}{ N. } & \multicolumn{4}{|c|}{ Pre-test } & \multicolumn{4}{|c|}{ Post-test } & \multicolumn{4}{|c|}{ (Post-Pre)-test } \\
\hline & & Mean & S.D. & $\mathrm{t}$ & $\mathrm{p}$ & Mean & S.D. & $\mathrm{t}$ & $\mathrm{p}$ & Mean & S.D. & $\mathrm{t}$ & $\mathrm{p}$ \\
\hline A & 51 & 55.61 & 12.73 & \multirow[t]{2}{*}{-1.17} & \multirow[t]{2}{*}{0.246} & 81.22 & 12.13 & \multirow[t]{2}{*}{2.945} & \multirow[t]{2}{*}{$0.004 * *$} & 25.61 & 14.41 & \multirow[t]{2}{*}{4.056} & \multirow{2}{*}{$\begin{array}{l}0.000 \\
* * *\end{array}$} \\
\hline $\mathrm{B}$ & 49 & 58.86 & 15.05 & & & 74.37 & 11.07 & & & 15.51 & 10.00 & & \\
\hline
\end{tabular}

$\mathrm{A}=$ Deductive group, $\mathrm{B}=$ Inductive group, ${ }^{* *}=\mathrm{p}<0.01, * * *=\mathrm{p}<0.001$

Table 2. Students' Learning Outcomes within Each Individual Group (pair t-test)

\begin{tabular}{l|l|l|l|l|l|l|c}
\hline \multirow{2}{*}{ Class } & \multirow{2}{*}{ N. } & \multicolumn{2}{|c|}{ Pre-test } & \multicolumn{2}{c|}{ Post-test } & \multirow{2}{*}{$\mathrm{t}$} & \multirow{2}{*}{$\mathrm{p}$} \\
\cline { 3 - 7 } & & Mean & S.D. & Mean & S.D. & & \\
\hline A (Deductive Group) & 51 & 55.61 & 12.73 & 81.22 & 12.13 & -12.70 & $0.000^{* * *}$ \\
\hline B (Inductive Group) & 49 & 58.86 & 15.05 & 74.37 & 11.07 & -10.85 & $0.000^{* * *}$ \\
\hline *** $=\mathrm{p}<0.001$
\end{tabular}

Table 3. Pre-, Post-, (Post-Pre)- test Scores Difference between FI/FD Students (ANOVA)

\begin{tabular}{|c|c|c|c|c|c|c|c|c|c|c|}
\hline \multirow{2}{*}{$\begin{array}{l}\text { Cognitive } \\
\text { Style }\end{array}$} & \multirow[t]{2}{*}{$\mathbf{N}$} & \multicolumn{3}{|c|}{ Pre-test } & \multicolumn{3}{|c|}{ Post-test } & \multicolumn{3}{|c|}{ (Post-Pre)-test } \\
\hline & & Mean & SD. & $\mathbf{p}$ & Mean & SD. & $\mathbf{p}$ & Mean & SD. & $\mathbf{p}$ \\
\hline FI & 43 & 58.88 & 13.91 & \multirow[t]{3}{*}{0.483} & 76.79 & 13.67 & \multirow[t]{3}{*}{0.411} & 17.91 & 12.17 & \multirow[t]{3}{*}{0.191} \\
\hline FD & 27 & 54.74 & 12.00 & & 76.81 & 10.37 & & 22.07 & 13.67 & \\
\hline FN & 30 & 57.00 & 15.61 & & 80.33 & 11.43 & & 23.33 & 14.45 & \\
\hline
\end{tabular}

FI:GEFT 14-18, FD:GEFT 0-10, FN=GEFT 11-13

Table 4. Learning Outcomes Difference within Individual FI/FD Students (pair t-test)

\begin{tabular}{l|l|l|l|l|l|l|c}
\hline \multirow{2}{*}{ Cognitive style } & \multirow{2}{*}{ N. } & \multicolumn{2}{|c|}{ Pre-test } & \multicolumn{2}{c|}{ Post-test } & \multirow{2}{*}{$\mathrm{t}$} & $\mathrm{p}$ \\
\cline { 3 - 7 } & & Mean & S.D. & Mean & S.D. & & \\
\hline FI (GEFT 14-18) & 43 & 58.88 & 13.91 & 76.79 & 13.67 & -9.652 & $0.000^{* * *}$ \\
\hline FD (GEFT 0-10) & 27 & 54.74 & 12.00 & 76.81 & 10.37 & -8.390 & $0.000^{* * *}$ \\
\hline FN (GEFT 11-13) & 30 & 57.00 & 15.61 & 80.33 & 11.43 & -8.842 & $0.000^{* * *}$ \\
\hline
\end{tabular}

$* * *=\mathrm{p}<0.001$ 
Table 5. The Interactive Effect of Inductive/Deductive Approaches and FI/FD Cognitive Styles on Student Performance Difference (ANOVA) (N=100)

\begin{tabular}{l|c|c|c|c|c|c|c|c|c|c}
\hline \multirow{2}{*}{ Class } & \multirow{2}{*}{ N. } & \multicolumn{3}{c|}{ Pre-test } & \multicolumn{3}{c|}{ Post-test } & \multicolumn{3}{c}{ (Post-Pre)-test } \\
\cline { 3 - 11 } & & Mean & S.D. & $\mathrm{p}$ & Mean & S.D. & $\mathrm{p}$ & Mean & S.D. & $\mathrm{p}$ \\
\hline Deductive & & & & & & & & & & \\
FI & 23 & 58.87 & 12.52 & 0.243 & 80.52 & 13.74 & 0.698 & 21.65 & 13.05 & 0.195 \\
FD & 14 & 52.14 & 10.74 & & 80.00 & 11.42 & & 27.86 & 14.06 & \\
FN & 14 & 53.71 & 14.38 & & 83.57 & 10.38 & & 29.86 & 16.11 & \\
\hline Inductive & & & & & & & & & & \\
FI & 20 & 58.90 & 15.70 & 0.920 & 72.50 & 12.55 & 0.385 & 13.60 & 9.66 & 0.727 \\
FD & 13 & 57.54 & 13.07 & & 73.38 & 8.18 & & 15.85 & 10.47 & \\
FN & 16 & 59.88 & 16.53 & & 77.50 & 11.11 & & 17.63 & 10.23 & \\
\hline
\end{tabular}

Table 6. Summary of FI/FD Students' Pre-test, Post-test, and Learning Outcomes

\begin{tabular}{l|l|l}
\hline Test Score & Deductive Group & Inductive Group \\
\hline Pre-test & FI $>$ FN $>$ FD & FN $>$ FI $>$ FD \\
\hline Post-test & FN $>$ FI $>$ FD & FN $>$ FD $>$ FI \\
\hline (Post-test)-(Pre-test) & FN $>$ FD $>$ FI & FN $>$ FD $>$ FI \\
\hline
\end{tabular}

FI/FD Cutoff score $=$ Mean+-0.5SD

\section{Appendix English Tenses Comprehension Test}

1."Hurry up! We're waiting for you. What's taking you so long?"

"I__ for an important phone call. Go ahead and leave without me."
A. wait
B. will wait
C. am waiting
D. have waited

2."Robert is going to be famous someday. He _ _ in three movies already."

"I am sure he'll be a star."
A. has been appearing
B. had appeared
C. has appeared
D. appeared

3."Where's Polly?" "She .
A. is in her room studying
C. studies in her room
B. in her room is studying
D. has in her room studied

4. "Hello? Alice? This is Jeff. How are you?"

"Jeff? What a coincidence! I _ _ about you when the phone rang."
A. was just thinking
B. just thought
C. have just been thinking
D. was just thought

5. "What _ _ about the new simplified tax law?"

"It's more confusing than the old one."
A. are you thinking
B. do you think
C. have you thought
D. have you been thinking

6. "When is Mr. Fields planning to retire?"

"Soon, I think. He _ _ here for a long time. He'll probably retire either next year or the year after that."
A. worked
B. had been working
C. has been working
D. is working

7. "Why did you buy all this sugar and chocolate?" "I a delicious dessert for dinner tonight."
A. make
B. will make
C. am going to make
D. will have made 
8. "Les's go! What's taking you so long?” "I'll be there as soon as I _ my keys."
A. found
B. will find
C. find
D. am finding

9. Next week when there __ a full moon, the ocean tides will be higher.
A. is being
$\mathrm{B}$. is
C. will be
D. will have been

10. While I_ TV last night, a mouse ran across the floor.
A. watch
B. watched
C. was watching
D. am watching

11. Fish were among the earliest forms of life. Fish on earth for ages and ages.
A. existed
B. are existing
C. exist
D. have existed

12. The phone constantly since Jack announced his candidacy for president this morning.
A. has been ringing
B. rang
C. had rung
D. had been ringing

13. The earth on the sun for its heat and light.
A. is depend
B. depending
C. had depend
D. depends

14. I don't feel good. I home from work tomorrow.
A. am staying
B. stay
C. will have stayed
D. stayed

15. Today there are weather satellites that beam down information about the earth's atmosphere. In the last two decades, space exploration great contributions to weather forecasting.
A. is making
B. has made
C. made
D. makes

16. On July 20, 1696, Astronaut Neil Armstrong __ down onto the moon, the first person ever to set foot on another celestial body.
A. was stepping
B. stepped
C. has stepped
D. was step

17. The plane's departure was delayed because of mechanical difficulties. When the weary passengers finally boarded the aircraft, many were annoyed and irritable because they in the airport for three and a half hours.
A. are waiting
B. were waiting
C. have been waiting
D. had been waiting

18. If coastal erosion continues to take place at the present rate, in other fifty years this beach anymore.
A. doesn't exist
B. isn't going to exist
C. isn't existing
D. won't be existing

19. Homestead High School's football team a championship until last season, when the new coach led them to win first place in their league.
A. has never won
B. is never winning
C. had never been wining
D. had never won

20. Non-native speakers need many years of intensive language study before they can qualify as interpreters. By the end of this year, Chen English for three years, but he will still need more training and experience before he masters the language.
A. will be studying $\quad$ B. has studied
C. will have been studying
D. has been studying

21. We for a couple of days, so you won't be able to call us.
A. travel
B. will travel
C. will be traveling
D. will have traveled

22. "When are you going to ask your boss for raise?"

"_ to her twice already! I don't think she wants to give me one."
A. I've talked
B. I've been talking
C. I was talking
D. I'd talked

23. "Do you think Harry will want something to eat after he gets here?"

"I hope not. It'll probably be after midnight, and we _.."
A. are sleeping
B. will be sleeping
C. have been sleeping
D. be sleeping 
24. Paul, could you please turn off the stove? The potatoes for at least thirty minutes.
A. are boiling
B. boiling
C. have been boiling
D. were boiling

25. "Is it true that spaghetti didn't originate in Italy?"

"Yes. The Chinese spaghetti dishes for a long time before Marco Polo brought it back to Italy."
A. have been making
B. have made
C. had been making
D. make

26. "I once saw a turtle that had wings. The turtle flew into the air to catch insects."

"Stop kidding. I _ _ you!"
A. don't believe
B. am not believing
C. didn't believe
D. wasn't believing

27. "Could someone help me lift the lawnmower into the pickup truck?"

"I am not busy. I _ you."
A. help
B. will help
C. am going to help
D. am helping

28. Just relax, Antoine. As soon as your sprained ankle heals, you can play soccer again. At this time next week, you soccer again.
A. will playB. are playing
C. play
D. will be playing

29. "Are you going to be in town next Saturday?" "No, I my aunt."
A. will be in Chicago visiting
B. visit
C. am visiting
D. will have visited

30. I know you feel bad now, Tommy, but try to put it out of your mind. By the time you're an adult, you all about it.
A. forget
B. will have forgotten
C. will forget
D. forgot

31. Mary was born in 1975. By the year 2025, she on this earth for 50 years.
A. will have been living
B. is living
C. lives
D. had lived

32. After ten unhappy years, Janice finally quit her job. She along with her boss for a long time before she finally decided to look for a new position.
A. hadn't been getting
B. isn't getting
C. didn't get
D. hasn't been getting

33. They about something when I walked into the room.
A. were arguing
B. argued
C. had argued
D. have argued

34. At one time, huge prehistoric reptiles dominated the earth. This Age of Dinosaurs present Age of Mammals has lasted to date.
A. lasted
B. was lasting
C. has lasted
D. had lasted

35. Jim, why don't you take some time off? You too hard lately. Take a short vacation.
A. worked
B. work
C. were working
D. have been working

36. The city is rebuilding its dilapidated waterfront, transforming it into a pleasant and fashionable outdoor mall. Next summer when the tourists arrive, they 104 beautiful new shops and restaurants in the area where the old run-down waterfront properties used to stand.
A. will found
B. will be finding
C. will have found
D. will find

37. A minor earthquake occurred at 2:07 A.M. on January3. Most of the people in the village at the time and didn't even know it had occurred until the next morning.
A. slept
B. had slept
C. were sleeping
D. sleep

38. The little girl started to cry. She her doll, and no one was able to find it for her.
A. has lost
B. had lost
C. was losing
D. was lost

39. What? He got married again? At this rate, he a dozen wives by the time he dies.
A. has had
B. had had
C. has
D. will have had 
40. Jane's eyes burned and her shoulders ached. She at the computer for five straight hours. Finally, she took a break.
A. is sitting
B. has been sitting
C. was sitting
D. had been sitting

41. She will almost $\$ 1000$ by then.
A. save
B. have saved
C. have been saving
D. be saving

42. By the time I go to bed tonight, I my work for the day.
A. will finish
B. have finished
C. will have finished
D. finish

43. By next year, Roger will here for 10 years.
A. live
B. be living
C. have been living
D. be going to

44. Fatemach looked down to discover a snake at her feet. When she saw it, she
A. was screaming
B. had screamed
C. screamed
D. screams

45. By the time Alfonso finally graduated from high school, he seven different schools because his parents moved frequently.
A. attended
B. was attending
C. had attended
D. had been attending

46. By April, I my new car for a year.
A. have driven
B. will have been driving
C. will have been driven
D. will drive

47. I borrowed four books on gardening the last time I to the library.
A. go
B. went
C. had gone
D. have gone

48. Before I started the car, all of the passengers their seat belts.
A. will buckle
B. had buckled
C. buckle
D. have buckled

\section{Twelve Tenses and Their Corresponding Test Questions}

\begin{tabular}{|l|l|}
\hline Tenses & Question numbers \\
\hline Simple Present & 8.9 .13 .26$. \\
\hline Present Progressive & 1.3 .5 .14$. \\
\hline Present Perfect & 2.11 .15 .22$. \\
\hline Present Perfect Progressive & 6.12 .24 .35$. \\
\hline Simple Past & 16.34 .44 .47$. \\
\hline Past Progressive & 4.10 .37 .33$. \\
\hline Past Perfect & 19.38 .45 .48$. \\
\hline Past Perfect Progressive & 17.25 .32 .40$. \\
\hline Simple Future & 7.18 .27 .36$. \\
\hline Future Progressive & 21.23 .28 .29$. \\
\hline Future Perfect & 30.39 .41 .42$. \\
\hline Future Perfect Progressive & 20.31 .43 .46$. \\
\hline
\end{tabular}

